TITLE:

\title{
DESCRIPTION OF A NEW POLYCHAETE, NOTHRIA SHIRIKISHINAIENSIS n. sp. OF THE FAMILY EUNICIDAE
}

\author{
AUTHOR(S): \\ Imajima, Minoru
}

\section{CITATION:}

Imajima, Minoru. DESCRIPTION OF A NEW POLYCHAETE, NOTHRIA SHIRIKISHINAIENSIS n. SP. OF THE FAMILY EUNICIDAE. PUBLICATIONS OF THE SETO MARINE BIOLOGICAL LABORATORY 1960, 8(1): 55-58

\section{ISSUE DATE:}

1960-05-30

URL:

http://hdl.handle.net/2433/174702

RIGHT: 


\title{
DESCRIPTION OF A NEW POLYCHAETE, NOTHRIA SHIRIKISHINAIENSIS n. sp. OF THE FAMILY EUNICIDAE ${ }^{1)}$
}

\author{
Minoru IMAJIMA \\ Shirikishinai Marine Station for Biological Instruction, \\ Hokkaido Gakugei University
}

With 14 Text-figures

The genus Nothria belonging to the subfamily Onuphidinae, is characterized by having branchiae of a simple filamentous shape, that are rarely absent. So far as the author is aware, five species of the genus have been recorded from Japanese waters, i.e., N. macrobranchiata, N. conchylega, N. geophiliformis, N. holobranchiata and $N$. willemoesii, but none from Hokkaido.

In April of 1956, many specimens of a certain species referable to the genus Nothria, were collected on the shore near the Station at Shirikishinai. On a closer examination, it seems to the writer that the species is a new representative of the genus, as described in the paper.

Before proceeding further, the author wishes to tender his cordial thanks to Prof. Hideji Yamaguchi for his kind guidance during this investigation and for his aid in preparing this manuscript.

\section{Nothria shirikishinaiensis n. sp.}

Many complete specimens were collected, of which the largest one measuring $270 \mathrm{~mm}$ by $2 \mathrm{~mm}$ had 352 setigerous segments, but generally they have 180 to 210 setigerous segments. The color of the anterior end of the living animal is dark brown, with brilliant iridescence, and is somewhat lighter on the ventral surface and also gradually lightening towards the posterior end. In the anterior portion of the body at the upper and lower margins of each segment are transverse bands of black pigment but the prostomium has no pigment with the exception of a pigmental patch on the mid-dorsal line. Though the base of the dorsal cirri are colored by the pigment, all tentacles and the dorsal cirri have uncolored tips.

1) Contribution No. 3 from the Shirikishinai Marine Station for Biological Instruction, Hokkaido Gakugei University.

Publ. Seto Mar. Biol. Lab., VIII (1), 1960. (Article 5) 
Five of the tentacles are distally tapered and provided with ceratophore at the base. The median tentacle has a ceratophore with six shorter articles and reaches backwards to the 5th setigerous segment. The lateral tentacles are slightly longer in size than the median one and reache almost as far as the 7th setigerous segment with 11 shorter articles. Though a pair of obscure dusky spots appears on the bases of the outer paired tentacles, there is no distinct eye. The peristomium is rather shorter in length than the 1st chaetiger, and bears a pair of smooth tentacular cirri (Fig. 1).

The branchia first appears on the 1st chaetiger as a simple filament, and they are found in every chaetiger with the exception of about the last 40 segments. The first branchia is approximately equal in length to the dorsal cirrus, but others are longer.

The parapodium in the first five chaetiger is implanted at a place near the front edge of the segments, and is larger in size than those in the following chaetigers. Ventral cirri are cirriform through the 7th setigers and in succeeding parapodia they are replaced with pads. In the 1st parapodium (Fig. 2) there are 2 or 3 thick tridentate pseudocompound setae (Figs. 3,4) and 10 to 13 fine ones (Figs. 5,6). These tridentate pseudocompound setae possess hooded hooks and 3 to 4 capillary setae and the same number of acicula. The thickness of the fine tridentate pseudocompound setae is about a third of the thick ones. There are various sized distal pieces on these tridentate pseudocompound setae. On the 2nd parapodium the similar setae found in the 1st parapodium are observable, but the fine members among them are slender and more numerous than the 1st setigerous one (Fig. 7). The number of the setae is between 16 and 24 . In one specimen there is also a tooth of the thick pseudocompound seta and it exhibits a tetradentate appearance (Fig. 8). In the 3rd chaetiger the great majority of the finer tridentate pseudocompound setae are replaced by bidentate hooded pseudocompound setae which are moreover more slender than the former (Fig. 9). The 4 th parapodium has 2 or 3 thick tridentate pseudocompound setae, about 30 fine bidentate pseudocompound setae, a few capillary setae and acicula. In the 5th parapodium there are some pectinate setae (Fig. 10) bearing 8-11 teeth with asymmetrical lateral extension and they are found in the capillary setae bundle. The thick tridentate pseudocompound setae occur through the parapodia I-V. The fine bidentate pseudocompound setae are also replaced by capillary setae in the 8th chaetiger. Two bidentate hooded subacicular setae (Fig. 11) are present in each chaetiger throughout 11 th to 13 th chaetiger.

The proboscidial armature consists of well-developed maxilla (Fig. 12) and mandible (Fig. 13). The mandibles are long, slender and have thin calcified distal plates, and united at the distal end for a short distance. The maxilla including maxillary carriers and forceps is almost equal to the mandible in length. The carriers are basally drawn out into fine tips, slightly grooved near their anterolateral edge. The dental formula is $6-7: 6+7-9$ or $6+6-9$. The pygidium 


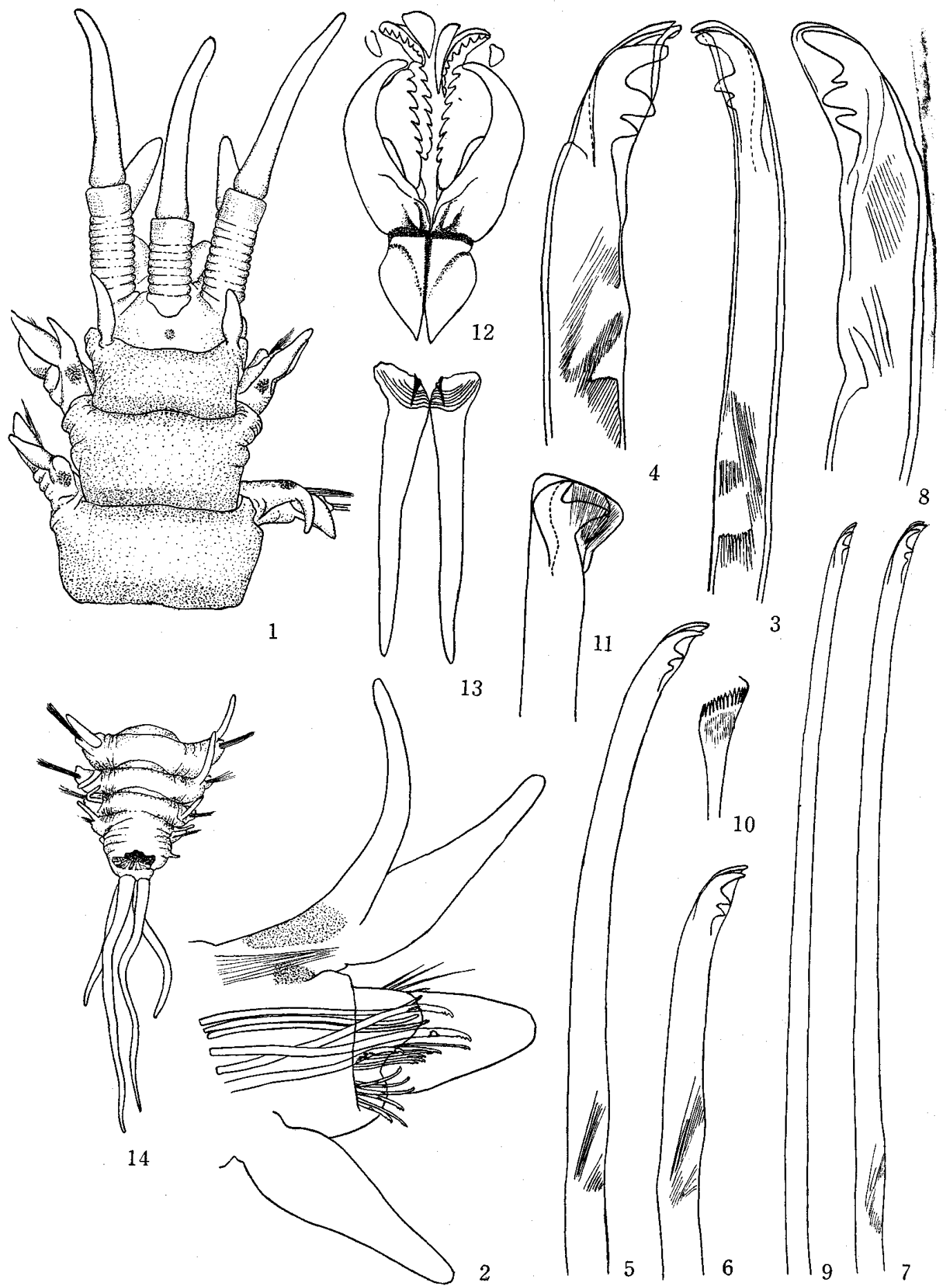

Figs. 1-14. Nothria shirikishinaiensis n. sp.

Fig. 1. Anterior end, dorsal view. $\times 18$; Fig. 2. 1st parapodium. $\times 53$; Figs. 3-4. Thick hooded tridentate pseudocompound setae from 1st parapodium. $\times 450$; Figs. 5-6. Fine hooded tridentate pseudocompound setae from 1st parapodium. $\times 450 ;$ Fig. 7 . The same from 2nd papapodium. $\times 450$; Fig. 8 . Tetradentate thick pseudocompound seta. $\times 450$; Fig. 9. Fine hooded bidentate pseudocompound seta from 3rd parapodium. $\times 450 ;$ Fig. 10. Pectinate seta from 20 th parapodium. $\times 300$; Fig. 11. Hooded subacicular seta. $\times 300 ;$ Fig. 12. Maxillae, dorsal view. $\times 28$; Fig. 13. Mandibles, ventral view. $\times 28$; Fig. 14. Posterior end, dorsal view. $\times 18$. 
bears 2 long dorsal and 2 short ventral anal cirri (Fig. 14).

Remarks: Of five species recorded from Japan, this species is closely allied to $N$. holobranchiata in having cirriform branchiae from the 1st chaetiger, but can be easily distinguished by the coloration of the dorsal surface of the body, by the shape of the maxillary carriers, by the dental formula and by appearance of the segment with ventral cirri. On the other hand, this species is also allied to the species found on the Pacific coast of North America, N. iridescens and $N$. elegans in appearance of the branchia from the same segment, but it is distinguishable from them in the following characteristics. According to HARTMAN's description $N$. iridescens has hooded tridentate seta as far as the 5th parapodium and has also bidentate setae without hood in same parapodium. But those of $N$. shirikishinaiensis are replaced perfectly or largely with bidentate hooded pseudocompound setae in the 3rd chaetiger, and the non-hooded bidentate seta is not found in the present species. In $N$. elegans the 1st and 2nd parapodia bear almost entirely bidentate setae, while in $N$. shirikishinaiensis bidentate seta disappears from these parapodia and it appears from the 3rd parapodium as fine hooded pseudocompound seta. The number of segments with ventral cirri and subacicular hooks in this species is different from the number in $N$. elegans.

Locality and habitat: The species was found in the sand of a Zostera-bed near the low-tide mark at Shirikishinai on the southern coast of Hokkaido. The tubes are made of a soft membranous substance and thickly and entirely coated with fine sand.

\section{LITERATURE CITED}

Crossland, C. 1903. On the marine fauna of Zanzibar and British East Africa, from collections made by Cyvil Crossland in the years 1901 and 1902. Polychaeta. Proc. Zool. Soc. London, pt. 2 : 129-144.

Hartman, O. 1944. Polychaetous annelids. Pt. V. Eunicea. Allan Hancock Pacific Exped., vol. 10: 1-238.

IzukA, A. 1912. The Errantiate Polychaeta of Japan. Jour. Coll. Sci., Imp. Univ. Tokyo, vol. 30 : $1-262$.

Johnson, P. H. 1901. The Polychaeta of the Puget Sound region. Proc. Boston Soc. Nat. Hist., vol. $29: 381-437$.

Marenzeller, E. v. 1879. Südjapanische Anneliden. I. Denkschr. Akad. Wiss. Wien, vol, $41: 1-46$.

MOORE, J.P. 1911. The polychaetous annelids dredged by the U.S. S. Albatross off the coast of southern California in 1904. III. Euphrosynidae to Goniadidae. Proc. Acad. Nat. Sci. Philadelphia, vol. $63: 234-318$.

Uschakov, P. V. 1955. Polychaetous annelids of Far Eastern Sea. Akad. Nauk USSR, vol. 56 : $1-445$.

Wesenberg-Lund, E. 1949. Polychaetes of the Iranian Gulf. Danish Sci. Invest. Iran, pt. 4: 247400. 